\title{
RELEVANSI STRUKTUR KEPEMILIKAN TERHADAP NILAI PERUSAHAAN PADA PT. AKR CORPORINDO, TBK PERIODE 2011-2020
}

\author{
Erwin Munandar \\ Institut Agama Islam Sukabumi \\ munandarwin@gmail.com \\ Hamdan Fathoni \\ Sekolah Tinggi Ilmu Ekonomi dan Bisnis Syariah Nahdlatul Ulama Garut \\ hamdanfathoni2014@gmail.com
}

\begin{abstract}
The value of the company becomes very important for the company or the holders of stock. Each party has its view on the value of the company, the similarity is to want the value of the company to be in a high position. Managerial ownership is the manager's shareholding where the manager is not only involved in managing the company but also involved in the impact of management decisions. Institutional ownership is the shareholding of another company that has a function as a management supervisor. This examination utilizes unmistakable techniques and quantitative methodologies utilizing optional information upheld by writing and documentation considers. The results showed partially both variables had no significant influence on the value of the company. Similarly, simultaneously it has no significant influence on the value of the company.
\end{abstract}

Keywords: Managerial Ownership, Institutional Ownership, Corporate Value.

\begin{abstract}
ABSTRAK
Nilai perusahaan ternyata menjadi vital bagi perusahaan atau investor. Masingmasing pihak memiliki pandangan tersendiri mengenai nilai perusahaan, kesamaannya ialah menginginkan nilai perusahaan berada pada posisi tinggi. Kepemilikan manajerial ialah kepemilikan saham manajer dimana manajer tidak hanya terlibat dalam mengelola perusahaan namun juga terlibat pada dampak dari keputusan manajemen. Kepemilikan institusional merupakan kepemilikan saham dari perusahaan lain yang memiliki fungsi sebagai pengawas manajemen. Penelitian ini menggunakan teknik yang jelas dan metodologi kuantitaif dengan menggunakan informasi tambahan yang didukung oleh tulisan dan dokumentasi. Hasil penelitian menunjukkan secara parsial kedua variabel tidak berdampak besar pada nilai perusahaan. Begitupun secara simultan tidak berdampak besar pada nilai perusahaan.
\end{abstract}

Kata Kunci: Kepemilikan Manajerial, Kepemilikan Institusional, Nilai Perusahaan. 


\section{PENDAHULUAN}

Perusahaan merupakan sekolompok orang terdiri dari dua atau lebih yang mengejar tujuan yang sama dengan aktivitasnya memproduksi dan mendistribusikan barang demi mendapatkan keuntungan dan dalam rangka memenuhi permintaan pasar. Perkembangan pasar modal mendorong perusahaan untuk mampu bersaing denggan perusahaan lain. Untuk mencapai tujuannya yaitu memaksimalkan laba, selain itu keberhasilan organisasi/perusahaan dapat tercermin dalam harga sahamnya. Jika harga sahamnya tinggi, berarti organisasi/perusahaaan tersebut memiliki nilai perusahaan yang besar.

Berdirinya sebuah perusahaan tentunya memiliki tujuan yaitu meningkatkan nilai perusahaan secara berkelanjutan. Nilai perusahaan merupakan pandangan investor terhadap suatu potensi perusahaan dalam mengolah sumber daya yang tersedia untuk memaksimalkan laba. Tingkat keberhasilan perusahaan dalam meningkatkan nilai perusahaan akan berdampak pada penilaian baik dari para investor (Tambalean et al., 2018). Karena pada dasarnya tujuan utama perusahaan ialah memaksimalkan profit dengan memberdayakan sumber daya yang tersedia dengan begitu dapat meningkatkan nilai pasar atas harga saham perusahaan yang bersangkutan. Tujuan ini berupa garis besar saja karena pada dasarnya dapat dipengaruhi oleh keputusan dibidang keuangan (Tika, 2012).
Nilai perusahaan juga dapat digambarkan sebagai berkembangnya pendukung keuangan dalam jangka panjang sehingga tujuan perusahaan dalam jangka panjang adalah untuk meningkatkan nilai perusahaan. Pendukung keuangan yang berkembang secara teratur diartikan sebagai ekspansi biaya pasar di bursa efek (Hanafi, 2008). Kepemimpinan perusahaan diperlukan agar perusahaan berjalan dengan baik. Harga pasar saham adalah gambaran dari pilihan setiap pilihan, dengan demikian nilai perusahaan kada bagian dari kegiatan manajemen (Suastini et al., 2016).

Saat ini isu struktur kepemilikan perusahaan publik semakin sentral dengan adanya konflik keagenan dalam litarature keuangan. Perusahaan yang semakin besar membutuhkan tenaga ahli untuk mengelolanya dengan adanya tenaga ahli ini dan berbagai stakeholder yang terlibat dalam perusahaan akan memicu terjadinya konflik keagenan. Masalah ini terdiri dari dua jenis yaitu masalah keagenan antara perusahaan dengan investor dan antara pemegang saham mayaroitas dan minoritas (Nuraina, 2012).

Selain itu konflik keagenan terjadi karena adanya tujuan yang berbeda antara pihak investor dengan pihak manajemen. Kepentingan pemegang saham ingin mendapatkan keuntungan melalui pembagian dividen yang tinggi. Namun pihak manajemen berkepentingan dalam pertumbuhan perusahaan karena perusahaan akan memberikan keselamatan kerja, promosi dan kompensasi bagi pihak- 
pihak yang terlibat (Sintyawati, Ni Luh Ary, 2018).

Upaya manajemen untuk menjaga nilai perusahaan yaitu dengan memaksimalkan komposisi struktur kepemilikan. Struktur kepemilikan diwakilkan oleh kepemilikan manajerial dan kepemilikan institusional. Kepemilikan manajerial adalah kepemilikan bersama dari dewan perusahaan. Digunakan untuk menyamakan persepsi antara investor dengan manajer. Karena manajer dapat mengalami sendiri keputusan investasi yang dibuat, apakah bermanfaat atau beresiko (Budianto \& Payamta, 2014). Semakin penting tingkat kepemilikan manajerial semakin besar keinginannya untuk mengkonsolidasikan kepentingan investor dan manajer, sehingga meningkatkan nilai perusahaan (Candradewi \& Sedana, 2016).

Kepemilikan manajerial di asumsikan sebagai upaya untuk mengendalikan dari pihak internal bertugas untuk mengontrol agar tidak terjadi konflik keagenan. Beberapa studi empiris mengenai pengaruh kepemilikan manajerial terhadap nilai perusahaan telah ditemukan hasil yang berbeda-beda. Sintyawati dkk mengemukakan hasil bawah Kepemilikan Manajerial berpengaruh terhadap Nilai Perusahaan (Sintyawati, Ni Luh Ary, 2018). Selaras dengan penelitian yang dilakukan oleh Sientara dkk bahwa kepemilikan manajerial berpengaruh terhadap nilai perusahaan (Sienatra et al., 2015).
Namun berbeda halnya dengan hasil studi yang dilakukan oleh Wayudi dkk bahwa kepemilikan manajerial tidak berpengaruh signifikan terhadap nilai perusahaan (Nurkhin et al., 2017). Selaras dengan penelitian yang dilakukan oleh Garcia Meca dan Shancez Ballesta bahwa kepemilikan manajerial tidak berpengaruh terhadap nilai perusahaan (Meca \& Ballesta, 2013)

Kepemilikan institusional adalah kepemilikan saham dalam suatu organisasi/perusahaan, misalnya agen asuransi, bank, ventura, atau kepemilikan institusional lainnya (Ismiati \& Yuniati, 2017). Adanya kepemilikan ini berperan untuk mengawasi manajemen terutama dalam hal pengambila keputusan. Dengan begitu pemegang saham akan semakin terjamin kemakmurannya karena kepemilikan instutusional memiliki pengaruh besar dalam pasar modal(Nuraina, 2012).

Bukti empiris mengenai pengaruh kepemilikan institusional terhadap nilai perusahaan dijelaskan oleh hasil penelitian yang dilakukan oleh Lestari bahwa kepemilikan institusional berpengaruh signifikan terhadap nilai perusahaa (Lestari, 2017). Sejalan dengan penelitian yang dilakukan oleh Sujoko dan Subiantoro membuktikan bahwa kepemilikan institusional berpengaruh signifikan terhadap nilai perusahaan. Semakin besar kepemilikan institusional maka akan semakin efisien dalam pemanfaatan aktiva perusahaan dan diaharapkan dapat mengurangi pemborosan terhadap manipulasi profit yyang dilakukan oleh 
manajemen dengan begitu dapat meningkatkan nilai perusahaan (Sujoko \& Subiantoro, 2007)

Namun terdapat juga bukti empiris yang menyatakan bahwa kepemilikan institusional tidak berpengaruh signifikan terhadap nilai perusahaan berdasarkan hasil penelitian yang dilakukan oleh Ayu dan Sumadi (Ayu \& Sumadi, 2019). Sama halnya dengan penelitian yang dilakukan oleh Sofyaningsih dan Hardianingsih menyatakan bahwa kepemilikan institusional tidak berpengaruh terhadap nilai perusahaan (Sofyaningsih \& Hardianingsih, 2011).

Penelitian ini menggunakan objek pada perusahaan yang bergerak di bidang industri kimia yang tercatat di Jakarta Islamic Index (JII) yaitu PT. AKR Corporindo, Tbk periode 2011-2020, berikut data penelitan disajikan dalam bentuk tabel.

\section{Tabel 1 Data Kepemilikan Manajerial, Kepemilikan Institusional, dan Nilai Perusahaan pada PT. AKR Corporindo periode 2011-2020}

\begin{tabular}{|c|c|c|c|}
\hline Tahun & $\begin{array}{c}\text { Kepemilikan } \\
\text { Manajerial }\end{array}$ & $\begin{array}{c}\text { Kepemilikan } \\
\text { Institusional }\end{array}$ & Nilai Perusahaan \\
\hline 2011 & 0,87 & 59,67 & 5,00 \\
\hline 2012 & 0,52 & 59,22 & 24,6 \\
\hline 2013 & 2,51 & 59,18 & 26,1 \\
\hline 2014 & 0,73 & 58,78 & 19,8 \\
\hline 2015 & 0,68 & 59,17 & 27,3 \\
\hline 2016 & 0,71 & 58,58 & 25,6 \\
\hline 2017 & 0,57 & 58,47 & 21,8 \\
\hline 2018 & 0,67 & 58,51 & 11,5 \\
\hline 2019 & 0,65 & 59,01 & 23,9 \\
\hline 2020 & 0,66 & 59,6 & 11,6 \\
\hline
\end{tabular}

Sumber data: laporan keuangan tahunan PT. AKR Corporindo, Tbk

Berdasarkan data yang diperoleh adanya ketidaksesuaian dengan teori. Semakin penting kepemilikan dewan, semakin rendah kecenderungan para eksdekutif untuk meningkatkan pemanfaatan aset yang mendorong peningkatan nilai perusahaan. Sehingga jika kepemilikian manajerial naik maka akan diikuti oleh kenaikannya. Kepemilikan institusional dapat menangani administrasi melalui interaksi pengawasan yang kuat untuk menghindari kegiatan kegiatan dewan dalam mengawasi pendapatan. Kepemililikan institusional dapat menjadi sistem yang solid untuk menginspirasi para pemimpin untuk meningkatkan presentase. Jadi, jika kepemilikan institusional berkembang, itu akan diikuti oleh nilai perusahaan. 
Pada tahun 2012 kedua variabel mengalami penurunan namun nilai perusahaan naik. Selanjutnya pada tahun 2013 hanya kepemilikan konstitusional saja yang mengalami penurunan. Selanjutnya menginjak tahun 2015 kepemilikan manajerial menurun sedangkan kepemilikan institusional dan nilai perusahaan meningkat. Lalu pada tahun 2016 hanya kepemilikan institusional saja yang mampu meningkat. Lalu pada tiga tahun terakhir terjadi ketidak konsistenan dari ketiga variabel tersebut. Maka dari itu dengan adanya ketidaksesuaan antara teori dengan data menjadi latar belakang dilakukannya penelitian ini.

\section{Tinjauan Pustaka}

\section{Kepemilikan Manajerial}

Kepemilikan manajerial ialah proporsi pemegang saham dari manajeemn yang sexara aktif ikut serta dalam pengambilan keputusan perusahaan (direktur dan komisaris) (Pujiati \& Widanar, 2009). Menruut Hermawan Darwis kepemilikan manajerial adalah kepemilikan saham dari pihak manajemen yang memiliki hak untuk ikut serta dalam pengambilan keputusan perusahaan (Darwis, 2009). Kepemilikan ini dapat menyeimbangkan antara kepentingan investor dengan emiten karena akan merasakan dampak atas keputusan yang diambil. Menurut Jensen semakin besar proporsi kepemilikan manajerial pada perusahaan akan dapat menyatukan kepentingan antara manajer denagn pemegang saham (Jensen \& Meckling, 1976). Berdasarkan uraian yang dipaparkan maka kepemilikan manajerial dapat didefinisikan sebagai kepemilikan saham yang berada pada pihak manajemen menimbulkan peran ganda sebagai bagian dari investor dan emiten.

\section{Kepemilikan Institusional}

Kepemilikan institusional menurut Jensen dan Meckling ialah kepemilikan yang memiliki peran sangat penting dalam meminimalkan konflik keagenan yang terjadi antara manajer dan pemegang saham (Jensen \& Meckling, 1976). Keberadaan kepemilikan ini dianggap mampu menjadi upaya untuk memonitoring setiap keputusan manajer. Kepemilikan ini umumnya dimiliki oleh institusi yang bergedak di bidang asuransi, perusahaan investasi, maupun kepemilikan institusi lainnya. Proporsi kepemilikan saham yang dimiliki oleh pemilik institusi dan blockholders pada akhir tahun. Yang dimaksud dengan blockholders ialah kepemilikan individu atas nama perorangan diatas 5\% yang tidak termasuk dalam kepemilikan manajerial. Pemegang saham ini termasuk dalam kepemilikan institusional karena pemegang saham blockholders (Sukirmi, 2012). Berdasarkan uarian diatas maka dapat didefiniskan kepemilikan institusional sebagai kepemilikan saham yang dimiliki oleh institusi lain dengan jumlah kepemilikan saham yang besar.

\section{Nilai Perusahaan}

Nilai perusahaan dapat didefiniskam sebagai wujud dari kemakmuran pemegang saham secara maksimum apabila 
harga saham mengalami peningkatan, untuk dapat meningkatkannya maka para pemodal mencari tempat yang terpercaya untuk mengelolanya (Nurlela \& Islahudin, 2008). Samuel menyebutkan bahwa nilai perusahaan factor yang paling penting bagi investor, karena merupakan bagian dari indikator bagi pasar menilai perusahaan secara keseluruhan. Husnan menyebutkan nilai perusahaan adalah nilai wajar sebuah perusahaan menjadi gambaran berbagai persepsi investor terhadap emiten yang bersangkutan (Husnan, 2003). Adapun menurut Kewon nilai perusahaan merupakan nilai pasar atas berbagai surat berharga hutang maupun ekuitas perusahaan yang beredar (Keown, 2010). Dan Menurut Weston and Copeland nilai perusahaan ialah nilai wajar perusahaan yang menggambarkan persepsi investor terhadap emiten yang bersangkutan (Weston \& Copeland, 1992).

Suharli berpendapat terdapat beberapa pengukur nilai perusahaan di antaranya ialah: (1) pendekatan laba antara lain metode rasio tingkat laba atau price earning ratio metode kapitalisasi proyeksi laba; (2) pendekatan arus kas antara lain metode diskonto arus kas; (3) pendekatan dividen antara lain metode pertumbuhan dividen; (4) pendekatan aktiva antara lain metode penilaian aktiva; (5) pendekatan harga saham; pendekatan economics value added (EVA) (Suharli, 2006).

Menurut Brigham dan Houston terdapat beberapa pendekatan analisis rasio dalam penilaian market value di antaranya: (1) price earnings ratio (PER); (2) price book value ratio (PBV); (3) market book ratio (MBR); (4) dividen yield ratio dan (5) dividen payout ratio (DPR) (Brigham \& Gapenski, 1996).

\section{Metodologi}

Pada penelitan ini menggunakan metode deskriptif melalui pendekatan kuantitatif yang menguraikan data berbentu numerik, dan hubungan antar variabel melalui analisis menggunakan alat uji statistik. Data yang dipakai berasal dari laporan keuangan PT. AKR Corporindo, Tbk periode 2011-2020 yang menajdi objek dalam penelitian ini di unduh dari website resmi perusahaan yaitu www.akr.co.id

\section{Tabel 2 Operasionalisasi Variabel Penelitian}

\begin{tabular}{|l|l|l|l|l|}
\hline \multicolumn{1}{|c|}{ Variabel } & \multicolumn{1}{|c|}{ Definisi } & \multicolumn{1}{|c|}{ Indikator } & \multicolumn{1}{c|}{ Rumus } & Skala \\
\hline Kepemilikan & Kepemilikan & Jumlah Saham \\
Manajerial & manajerial adalah & Jumlah Saham Manajemen & Komisaris, \\
& kepemilikan \\
& bersama dario \\
& dewan & $\begin{array}{l}\text { Direksi, dan } \\
\text { Manajer, }\end{array}$ & & \\
& & & \\
\hline
\end{tabular}




\begin{tabular}{|c|c|c|c|c|}
\hline & $\begin{array}{l}\text { perusahaan. } \\
\text { Digunakan untuk } \\
\text { menyamakan } \\
\text { persepsi antara } \\
\text { investor dengan } \\
\text { manajer. }\end{array}$ & $\begin{array}{l}\text { Jumlah Saham } \\
\text { yang Beredar }\end{array}$ & & \\
\hline $\begin{array}{l}\text { Kepemilikan } \\
\text { Institusional }\end{array}$ & $\begin{array}{l}\text { Kepemilikan } \\
\text { saham dalam suatu } \\
\text { organisasi/perusah } \\
\text { aan, misalnya agen } \\
\text { asuransi, bank, } \\
\text { ventura, atau } \\
\text { kepemilikan } \\
\text { institusional } \\
\text { lainnya. }\end{array}$ & $\begin{array}{l}\text { Jumlah Saham } \\
\text { Institusi, } \\
\text { Jumlah Saham } \\
\text { Beredar }\end{array}$ & $=\frac{\text { Jumlah Saham Institusi }}{\text { Saham yg Beredar }} \times 100$ & Rasio \\
\hline $\begin{array}{l}\text { Nilai } \\
\text { Perusahaan }\end{array}$ & $\begin{array}{l}\text { Menggambarkan } \\
\text { berkembangnya } \\
\text { pendukung } \\
\text { keuangan dalam } \\
\text { jangka panjang } \\
\text { sehingga tujuan } \\
\text { perusahaan dalam } \\
\text { jangka panjang } \\
\text { adalah untuk } \\
\text { meningkatkan } \\
\text { nilai perusahaan. }\end{array}$ & $\begin{array}{l}\text { Market Price } \\
\text { per Share, } \\
\text { Book Value per } \\
\text { Share }\end{array}$ & $=\frac{\text { Market Price per Share }}{\text { Book Value per Share }} \times 100$ & Rasio \\
\hline
\end{tabular}

HASIL DAN PEMBAHASAN

Hasil Penelitian

Uji Normalitas
Perhitungan dalam pengujian ini menggunakan uji One-sample Kolmogrov Smirnov. Berikut ini adalah efek samping dari komputasi menggunakan SPSS 
Tabel 2 Hasil Uji Normalitas

One-Sample Kolmogorov-Smirnov Test

\begin{tabular}{|ll|r|}
\hline & & Unstandardized Residual \\
\hline Normal Parameters ${ }^{\mathrm{a}, \mathrm{b}}$ & & 10 \\
& Mean & .0000000 \\
Most Extreme Differences & Std. Deviation & 6.83050632 \\
& Absolute & .129 \\
& Positive & .128 \\
Test Statistic & Negative & -.129 \\
Asymp. Sig. (2-tailed) & & .129 \\
\hline
\end{tabular}

a. Test distribution is Normal

b. Calculated from data.

Sumber: Output SPSS versi 22.0

Mengacu pada tabel yang telah instrumen eksplorasi memiliki sirkulasi disajikan, diperoleh hasil uji normalitas sebesar 0,030. Dengan demikian, dapat disimpulkan penelitian konsisten dengan asumsi normalitas, dimana semua khas, karena $0,030<0,05$.

Uji Multikolinearitas

Dasar pengambilan keputusan pada uji ini diambil dengan nilai kewajaran $>0,1$ dan nilai $\mathrm{VIF}<10$.

Tabel 3 Uji Multikolinearitas

Coefficients ${ }^{a}$

\begin{tabular}{|ll|r|r|}
\hline \multirow{2}{*}{ Model } & \multicolumn{2}{|c|}{ Collinearity Statistics } \\
\cline { 3 - 4 } & Tolerance & \multicolumn{1}{c|}{ VIF } \\
\hline 1 & (Constant) & .967 & \\
& KM & .967 & 1.034 \\
& KI & 1.034 \\
\hline
\end{tabular}

a. Dependent Variabel : Nilai Perusahaan

Sumber: Output SPSS versi 22.0

Mengacu pada tabel tersebut, dilanjutkan.

diperoleh hasil kepemilikan institusional dan kepemilikan manajerial untuk tolerance $0,967>0,01$ dengan nilai VIF sebesar $1,034<10$. Dengan demikian disimpulkan bahwa multikolinearitas tidak muncul dalam model regresi ini, tidak ada hubugan antar variabel independen, dan penelitian dapat

\section{Uji Heterokedastisitas}

Uji heterokedastisitas diguakan untuk menunjukkan tidak adanya kesamaan varian. Menggunakan diagram pancar untuk melihat apakah penelitian ini heterokedastisitas. 


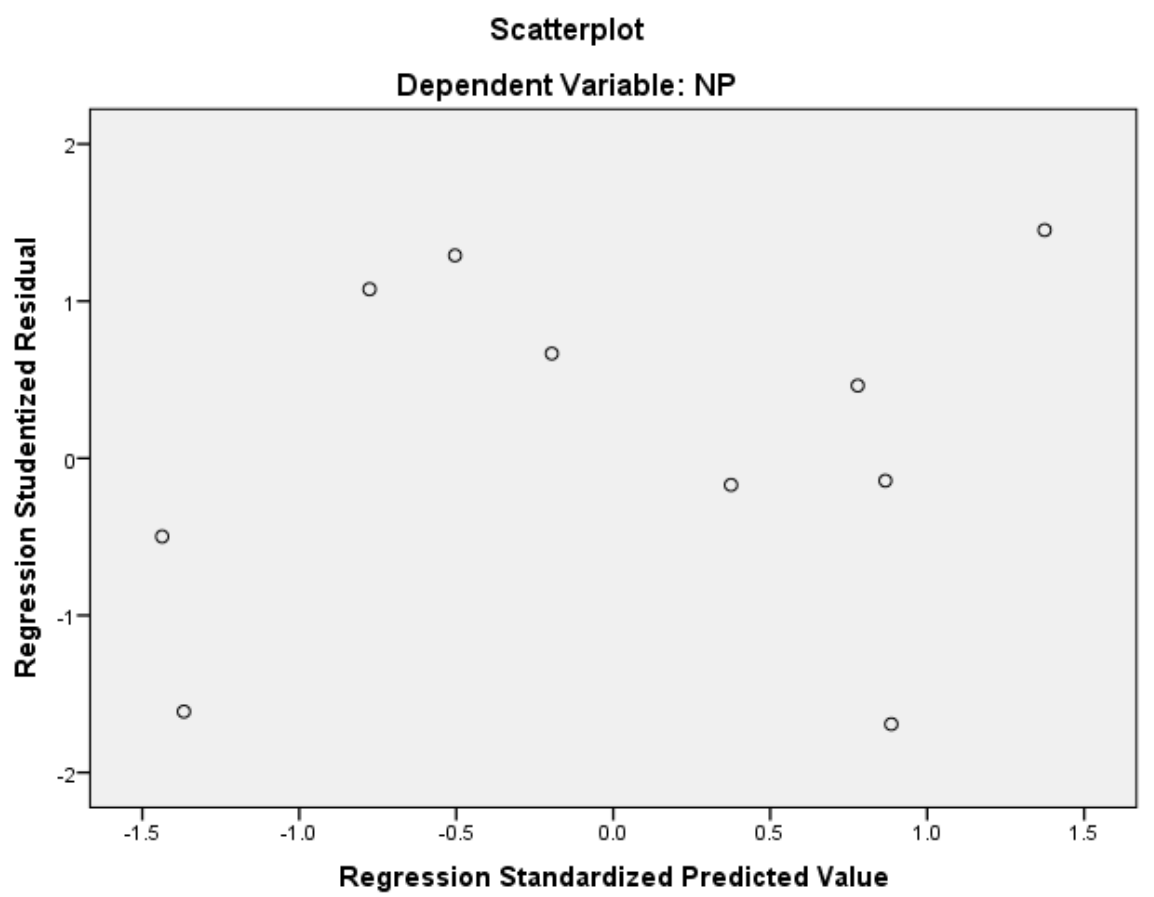

\section{Gambar 1 Hasil Uji Heterokedastisitas}

Sumber: Output SPSS versi 22.0

Berdasarkan diagram di atas, dapat Analisis Regresi Linear Berganda diduga bahwa informasi dalam Analisis ini digunakan untuk memupemeriksaan ini terhindar dari tuskan pengaruh faktor bebas terhadap heterokedastisitas mengingat informasi variabel terikat secara bersamaan. Berikut tersebut tersebar secara seampangan. ini konsekuensi dari pemeriksaan regresi linear sederhana dan juga berganda:

Tabel 4 Hasil Uji Regresi Berganda

Coefficients ${ }^{\mathrm{a}}$

\begin{tabular}{|c|c|c|c|c|c|}
\hline \multirow{2}{*}{} & \multicolumn{2}{|c|}{$\begin{array}{c}\text { Standardi } \\
\text { Unstandardized } \\
\text { Coefficients }\end{array}$} & $\begin{array}{c}\text { zed } \\
\text { Coefficients }\end{array}$ & \\
\cline { 2 - 4 } Model & $\mathrm{B}$ & Error & Beta & $\mathrm{t}$ & Sig. \\
\cline { 2 - 6 } (Constant) & 451.598 & 360.079 & & 1.254 & .250 \\
KM & 3.606 & 4.464 & .277 & .808 & .446 \\
KI & -7.370 & 6.112 & -.413 & -1.206 & .267 \\
\hline
\end{tabular}


a. Dependent Variabel: Nilai Perusahaan

Sumber: hasil output SPSS versi 22.0

Berdasarkan tabel di atas, model kondisi yang menyertainya diperoleh :

Nilai perusahaan $=451,598+3,606$

Kepemilikan Manajerial _ 7,370

Kepemilikan Institusional

Menyinggung kondisi persamaan, nilai tetap (a) yaitu 451,589. Angka ini menyiratkan bahwa nilai kepemilikan manajerial dan kepemilikan institusional tetap stabil, maka nilai perusahaan akan berniali 451,589.

Variabel kepemilikan manajerial memiliki nilai regresi 3,606. Ini merupakan

nilai positif, artinya jika proporsi pengurus bertambah satu persen maka nilai perusahaan akan berubah sebesar 3,606.

Terlebih lagi, variabel kepemilikian institusional memiliki nilai koefisien sebesar -7,370. Angka ini negatif, menyiratkan bahwa kepemilikian institusional telah meningkatkan satu persen dengan anggapan bahwa faktorfaktor lain stabil, kemudian, pada saat itu, nilai perusahaan akan berkurang 7,370.

\section{Hasil Korelasi dan Determinasi}

Berkut hasil pengujian korelasi dan determinasi yang telah dilakukan.

Tabel 5 Hasil Uji Korelasi dan Determinasi

Model Summary ${ }^{b}$

\begin{tabular}{|c|c|c|c|c|}
\hline Model & $\mathrm{R}$ & R Square & Adjusted R Square & Std. Error of the Estimate \\
\hline 1 & $.453^{\mathrm{a}}$ & .206 & -.021 & 7.74507 \\
\hline
\end{tabular}

a. Predictors : (Constant), Nilai Perusahaan

Sumber: output SPSS versi 22.0

\begin{abstract}
Mengacu hasil pengujian, menerangkan besarnya hubungan kepemilikan manajerial dan kepemilikan institusional terhadap nilai perusahaan sebesar 0,453 termasuk dalam kriteria sedang. Dan hasil R Square $\left(r^{2}\right)$ sebesar 0.206 atau sama dengan 20,6\%. Memiliki arti bawah nilai perusahaan dipengaruhi oleh kepemilikan manajerial dan kepemilikan institusional sebesar 20,6\% sisanya $79,4 \%$ dipengaruhi oleh faktor lain.
\end{abstract}

\section{Uji Hipotesis}

Uji

Pengaruh kepemilikan manajerial terhadap nilai perusahaan pada tabel diperoleh nilai t-test sebesar 0,808 dengan taraf kepentingan 0,446 . Hasil ini mengandung arti nilai signifikansi tidak memenuhi kriteria berpengaruh karena lebih besar daru 0,05. Pada penelitian ini 0,446>0,05 sehingga diperoleh bahwa 
kepemilikan manajerial berpengaruh tidak signifikan terhadap nilai perusahaan.

Berdasarkan tabel diatas diperoleh $t$ test-1,206 dengan taraf signifikansi sebesar 0,267 . Hasil ini menunjukkan bahwa nilai signifikansi tidak memenuhi kriteria berpengaruh sebab lebih besar dari 0,05.
Pada penelitian ini 0,267>0,05. Jadi diperoleh bahwa kepemilikan institusional tidak berdampak besar pada nilai perusahaan.

\section{Ujif}

Hasil dari uji $\mathrm{f}$ adalah sebagai berikut:

Tabel 6 Hasil Uji F

ANOVA $^{a}$

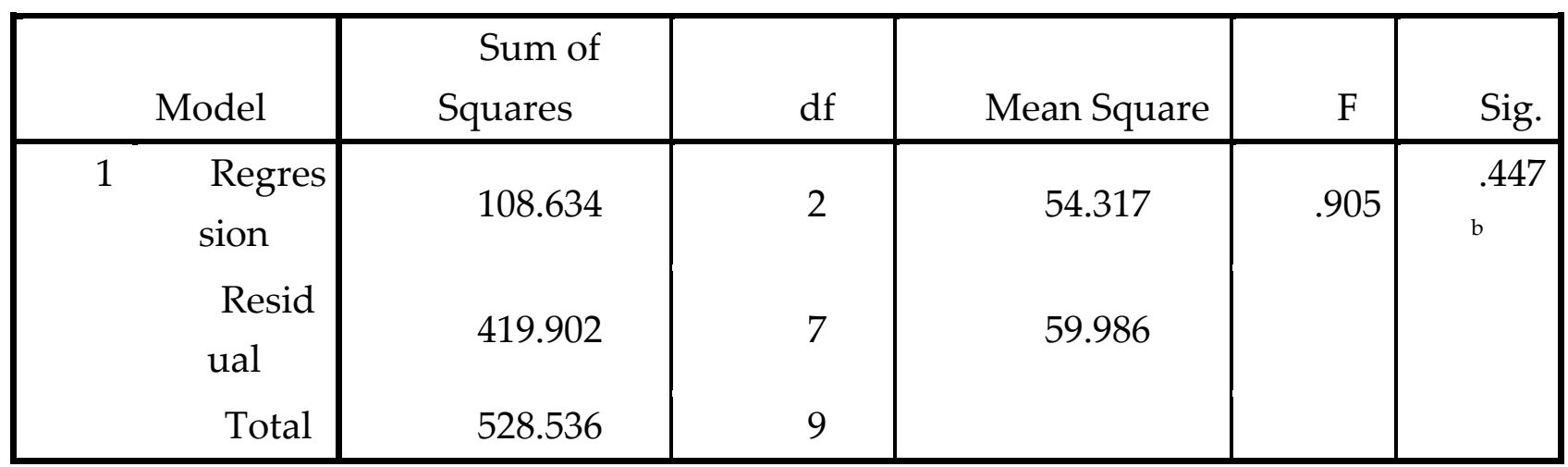

a. Dependent Variabel: Nilai Perusahaan

b. Predictors: (Cosntant), Kepemilikan Manajerial, Kepemilikan Institusional Sumber: Output SPSS versi 22

Disinggung hasil uji faktual yang tercatat pada tabel di atas, hasil $f$-statistic sebesar 0,905 dengan signifikansi 0,447 dengan signifikansi yang lebih menonjol dari 0,05. Selanjutnya, hasil yang diperoleh bahwa kepemilikan manajerial dan kepemilikan institusional tidak memiliki dampak besar pada nilai perusahaan.

\section{PEMBAHASAN HASIL PENELITIAN}

\section{Pengaruh Kepemilikan Manajerial} terhadap Nilai Perusahaan pada PT. AKR Corporindo, Tbk

Menurut teori keagenan pada dasarnya manajemen sebagai pemegang sagam mempercayai manajemen sebagai agen untuk mengelola perusahaan untuk kepentingan prinsipal. Namun tidak semua agen sejalan dengan prinsipal, pada kenyataannya benturan kepentinga ini sering terjadi, agen melakukan tindakan oporunistik sehingga terjadi konflik. Peningkatan kepemlikan ini agar dapat mengurangi masalah keagenan. Karena manajemen mempunyai dua peran sebagai agen dan sebagai prinsipal. Karena manajer akan merasakan konsekuensi dari keputusannya, mereka akan berhati-hati dalam menentukan pilihan dalam meningkatkan perusahaan (Nurkhin et al., 2017).

Hasil penelitian menunjukkan bahwa kepemilikan manajerial tidak berdampak 
besar pada nilai perusahaan. Hasil uji diperoleh $t$ hitung sebesar 0,808 dengan tingkat signifikansi 0,446. Akibatnya, efek samping dari penelitian tidak sesuai dengan hipotesis yang telah digambarkan.

Hasil penelitian ini tidak sesuai dengan teori yang dijelaskan. Besar kecilnya kepemilikan manajerial tidak dapat menguranhi biaya keagenan sehingga tidak dapat meningkatkan nilai perusahaan. Menurut teori stewardship para manajer tidak tertarik untuk tujuan individu tetapi lebih mementingan perusahaan. Teori ini berdasarkan pada teori psikologi dan sosiologi yang dirancang agar supervisor dirangsang untuk bertindak sesuai keinginan. Jadi tingkat kepemilikan kepemilikan tidak dapat memastikan nilai perusahaan (Said, 2015).

Berdasarkan teori keagenan bahwa pada dasarnya manajemen sebagai principal bertugas untuk mengelola perusahaan dengan baik yang dipercaya oleh pihak investor. Namun pada kenyataannya keinginan investor dengan principal sering berbenturan, pihak principal cenderung oportunistik sehingga menimbulkan masalah keagenan. Padahal peningkatan kepemilikan manajerial sebagai upaya untuk meminimalisir terjadi konflik keagenan. Dalam konsep ini akan adanya dua peran sekaligus, manajemen akan berperan sebagai agen sekaligus jugs principal. Manajemen akan lebih berhatihati dalam pengambilan keputusan karena secara langsung akan merasakan dampaknya. Maka dari itu tingginya kepemilikan manajerial akan meningkat nilai perusahaan (Jensen \& Meckling, 1976).

Hasih penelitian ini mendukung penelitian yang dilakukan oleh Wahyudi dkk (2017) bahwa kepemilikan manajerial tidak berpengaruh signifikan terhadap nilai perusahaan. Selaras dengan penelitian yang dilakukan oleh Garcia Meca dan Shancez Ballesta (2013) bahwa kepemilikan manajerial tidak berpengaruh terhadap nilai perusahaan.

\section{Pengaruh Kepemilikan Institusional terhadap Nilai Perusahaan pada PT. AKR Corporindo, Tbk}

Peningkatan pada kepemilikan institusional diharapkan agar dapat mengurangi biaya agensi atau agency cost of debt. Karena semakin banyak proporsinya akan semakin terlibat dalam mengawasi manajemen menjalankan operasional perusahaannya, sehingga akan dapat menguntungkan pemegang saham. Monitoring manajemen dalam keputusan pendanaan dapat mengurangi utang perusahaan, para eksekutif akan lebih berhati-hati dalam memberikan kredit karena membuat perusahaan gagal bayar (Warapsari \& Suaryana, 2016).

Hasil penelitian menunjukkan bahwa kepemilikan institusional tidak berdampak besar pada nilai perusahaan. Hasil uji faktual ini diperoleh nilai $t$ sebesar -1,206 dengan tingkat signifikansi sebesar 0,267. Dengan cara ini, konsekuensi dari penyelidikan tidak sesuai dengan hipotesis yang telah digambarkan.

Perusahaan induk memiliki kepemilikan instutusional dan terafiliasi satu 
sama lain di Indonesia masih menjadi bagian dari perusahaan keluarga, sehingga pengurusnya tetap keluarga. Karena keepmilikan institusional berasal dari pihak keluarga sehingga menjadi tidak independen sebagai pengawas walaupun kepemilikan ini berjumlah tinggi. Sehingga kondisi ini tidak dapat meminimalisir agnecy problem sehingga dapat mempengaruhi nilai pasar.

Kepemilikan institusional yang termasuk dalam kategori tinggi berkisar pada $67,9 \%$ yang merupakan pemilik mayoritas perusahaan. Menurut Pound, investor institusional pada umumnya berpihak pada pihak manajemen saja dengan menyampingkan kepentingan dari pemegang saham minoritas. Investor institusional merupakan pemilik sementara (transfer owner) sehingga investor ini hanya berfokus pada laba sekarang (current earning) maka perubahan laba akan dapat mempengaruhi keputusan investor institusional perusahaan. Bila di rasa perusahaan tidak dapat menghasilkan keuntungan yang besar maka investor institusional dapat menarik sahamnya yang mayoritas berjumlah besar jika hal ini terjadi maka akan menurunkan nilai saham secara keseluruhan. Maka dapat diartikan bahwa kepemilikan institusional belum mampu menjadi indicator yang dapat meningkatkan nilai perusahaan (Ayu \& Sumadi, 2019).

Struktur kepemilikan jika dimaksimalkan akan memberikan dampak baik terhadap nilai perusahaan. Dalam hal kepemilikan manajerial dapat menyesuaikan kepentingan investor, itu akan memiliki efek yang layak. Begitupun dengan kepemilikan institusional jika berjalan sebagaimaan mestinya sebagai pengawas yang independen akan memberikan kelancaran bagi perusahaan.

Hasil penelitian ini mendukung penelitian Ayu dan Sumadi (2019) menyatakan bahwa kepemilikan institusional tidak berpengaruh signifikan terhadap nilai perusahaan. Sama halnya dengan penelitian yang dilakukan oleh Sofyaningsih dan Hardianingsih (2011) menyatakan bahwa kepemilikan institusional tidak berpengaruh terhadap nilai perusahaan.

Pengaruh Kepemilikan Manajerial dan Kepemilikan Institusional terhadap Nilai Perusahaan pada PT. AKR Corporindo, Tbk

Nilai perusahaan merupakan faktor terpenting yang diperhitungkan perusahaan untuk membuat keputusan investasi. Tinggi rendahnya nilai perusahaan menjadi gambaran nilai perusahaan, jika nilai perusahaan tinggi maka menggambarkan keberhasilan perusahaan sehingga dapat memakmurkan para pemegang saham. Sehingga nilai perusahaan dianggap sebagai suatu pertimbangan yang sangat penting sebelum melalukan investasi (Arifianto \& Chabachid, 2016).

Bahwa kepemilikan manajerial dan kepemilikan institusional tidak berdampak besar pada nilai perusahaan. Dengan nilai uji $f$ sebesar 0,905 dengan signifikansi 0,447, lebih menonjol dari 0,05. 
Erwin Munandar \& Hamdan Fathoni 


\section{SIMPULAN}

Pada bagian akhir penelitian memiliki tiga kesimpulan. Pertama, kepemilikan manajerial tidak berdampak besar pada nilai perusahaan. Kedua, kepemilikan institusional berdampak besar pada nilai perusahaan. Ketiga, secara bersamaan kepemilikan manajerial dan kepemilikan institusional tidak berdampak besar pada nilai perusahaan dengan kontribusi sebesar 20,6\%. Implikasi dalam penelitian ini nampaknya pihak manajemen tidak dapat mengendalikan terjadinya agency cost karena terjadinya pertentangan kepentingan. Pihak manajemen yang lebih memperhatikan operasional perusahan dan pemegang saham berkeinginan mendapatkan imbal hasil yang besar. Sehingga pertentangan ini menimbulkan nilai perusahaan tidak meningkat.

\section{REFERENSI}

Arifianto, M., \& Chabachid, M. (2016). Analisis Faktor-Faktor Yang Mempengaruhi Nilai Perusahaan ( Studi Kasus Pada Perusahaan Yang Terdaftar Pada Indeks LQ-45 Periode 2011-2014). Diponegoro Journal Of Management, 5(1), 1-12.

Ayu, P. C., \& Sumadi, N. Ko. (2019). Pengaruh Kepemilikan Institusional dan Kepemilikan Manajerial terhadap Nilai Perusahaan. Jurnal Widya Alkuntansi, 1(1), 87-104.

Brigham, E. F., \& Gapenski, L. C. (1996). Intermediate Financial Management. The Dryden Press.

Budianto, W., \& Payamta, P. (2014). Pengaruh Kepemilikan Manajerial Terhadap Nilai Perusahaan Dengan Kebijakan Dividen Sebagai Variabel Moderasi. Assets: Jurnal Akuntansi Dan Pendidikan, 3(1), 13. https://doi.org/10.25273/jap.v3i1.1207

Candradewi, I., \& Sedana, I. B. P. (2016). PENGARUH KEPEMILIKAN MANAJERIAL , KEPEMILIKAN Fakultas Ekonomi dan Bisnis Universitas Udayana ( Unud ), Bali , Indonesia PENDAHULUAN Menghadapi persaingan bisnis yang kompetitif, perusahaan berusaha memperbaiki kinerja dan mengembangkan usaha untuk menca. E-Jurnal Manajemen Undud, 5(5), 3163-3190.

Darwis, H. (2009). Corporate Governance Terhadap Kinerja Perusahaan. Jurnal Keuangan Dan Perbankan, 13(3), 418-430.

Hanafi, M. (2008). Manajemen Keuangan. BPFE UGM.

Husnan, S. (2003). Manajemen Keuangan Teori Dan Penerapan (Keputusan Jangka Pendek). Buku 2 Edisi ke-4. BPFE Yogyakarta. 
Ismiati, P. I., \& Yuniati, T. (2017). Pengaruh Kepemilikan Manajerial, Kepemilikan Institusional, dan Kebijakan Hutang terhadap Kebijakan Dividen. Jurnal Ilmu Dan Riset Manajemen (JIRM), 6(3), 1-19. http://jurnalmahasiswa.stiesia.ac.id/index.php/jirm/article/view/1053

Jensen, M. ., \& Meckling, W. . (1976). Theory of the Firm: Managerial Behavior, Agency Cost and Ownership Structure. Journal of Financial Economics, 3(4).

Keown, A. . (2010). Manajemen Keuangan : Prinsip-Prinsip dan Aplikasi. Edisi ke-9. Indeks.

Lestari. (2017). Pengaruh Kepemilikan Institusional Dan Struktur Modal Terhadap Nilai Perusahaan. Jurnal Riset Manajemen Dan Bisnis (JRMB) Fakultas Ekonomi UNIAT, 2, 293-306. https://doi.org/10.36226/jrmb.v2is1.62

Meca, E. G., \& Ballesta, J. . S. (2013). Firm Value and Ownership Structure in the Spanish Capital Market. Corporate Governance; The International Journal of Business in Society, 11(1), 41-53.

Nuraina, E. (2012). Pengaruh Kepemilikan Institusional Dan Ukuran Perusahaan Terhadap Kebijakan Hutang Dan Nilai Perusahaan (Studi Pada Perusahaan Manufaktur Yang Terdaftar Di Bei). AKRUAL: Jurnal Akuntansi, 4(1), 51. https://doi.org/10.26740/jaj.v4n1.p51-70

Nurkhin, A., Wahyudin, A., \& Fajriah Aenul Septiani, A. (2017). Nilai Perusahaan Barang Konsumsi. Jurnal Akuntansi Multiparadigma JAMAL, 8(1), 1-227.

Nurlela, R., \& Islahudin. (2008). "Pengaruh Corporate Social Responsibility terhadap Nilai Perusahaan dengan Prosentase Kepemilikan Manajemen sebagai Variabel Moderating. Simposium Nasional Akuntansi XI.

Pujiati, D., \& Widanar, E. (2009). Pengaruh Struktur Kepemilikan Terhadap nilai perusahaan: Keputusan Keuangan sebagai Variabel Intervening. Jurnal Ekonomi Bisnis Dan Akuntansi Ventura, 12(1), 71-86.

Said, A. L. (2015). Corporate Social Responsibility dalam Perspektif Governance. Deepublish.

Sienatra, K. ., Sumiati, \& Andarwati. (2015). Struktur Kepemilikan sebagai Determinan Nilai Perusahaan. Jurnal Akuntansi Multiparadigma, 6(1), 124-132.

Sintyawati, Ni Luh Ary, M. R. D. S. (2018). Ni Luh Ary Sintyawati Made Rusmala Dewi $S$ PENGARUH KEPEMILIKAN MANAJERIAL, KEPEMILIKAN INSTITUSIONAL DAN LEVERAGE TERHADAP BIAYA KEAGENAN PADA PERUSAHAAN MANUFAKTUR. E-Jurnal Manajemen Unud, 7(2), 993-1020.

Sofyaningsih, S., \& Hardianingsih, P. (2011). Struktur Kepemilikan, Kebijakan Dividen, Kebijakan Utang dan Nilai Perusahaan. Dinamika Keuangan Perbankan, 3(1), 68-87. 
Suastini, N. M., Bagus, I., Purbawangsa, A., \& Rahyuda, H. (2016). PERTUMBUHAN PERUSAHAAN TERHADAP NILAI PERUSAHAAN PADA PERUSAHAAN MANUFAKTUR DI BURSA EFEK INDONESIA ( Struktur Modal sebagai Variabel Moderasi ) Fakultas Ekonomi Dan Bisnis Universitas Udayana ( Unud ), Bali , Indonesia Nilai perusahaan menggambarkan kema. E-Jurnal Ekonomi Dan Bisnis Universitas Udayana, 1(5), 143-172.

Suharli, M. (2006). Akuntansi untuk Bisnis Jasa dan Dagang. Graha Ilmu.

Sujoko, \& Subiantoro, U. (2007). Pengaruh Struktur Kepemilikan Saham, Leverage, Faktor Intern Dan Faktor Ekstern Terhadap Nilai Perusahaan. Jurnal Manajemen Dan Kewirausahaan, 9(1), 41-48.

Sukirmi, D. (2012). Pengaruh Kepemilikan Manajerial, Kepemilikan Institusional, Kebijakan Dividen, dan Kebijakan Hutang Analisis terhadap Nilai Perusahaan. Accounting Analysis Journal, 1(2), 1-12.

Tambalean, F. A. K., Manossoh, H., \& Runtu, T. (2018). Pengaruh Kepemilikan Manajerial Dan Kepemilikan Institusional Terhadap Nilai Perusahaan Pada Perusahaan Sektor Industri Barang Konsumsi Di Bei. Going Concern : Jurnal Riset Akuntansi, 14(1), 465473. https://doi.org/10.32400/gc.13.04.21255.2018

Tika, P. (2012). Budaya Organisasi dan Peningkatan Kinerja Perusahaan. Bumi Aksara.

Warapsari, A. A. A. U., \& Suaryana, I. G. N. A. (2016). Pengaruh Kepemilikan Manajerial Dan Institusional Terhadap Nilai Perusahaan Dengan Kebijakan Utang Sebagai Variabel Intervening. E-Jurnal Akuntansi Universitas Udayana, 16(3), 2288-2315.

Weston, J. F., \& Copeland, T. (1992). Managerial Finance. PT Gelora Aksara. 